\title{
人エ血管内シャントの長期成績
}

\author{
平中 俊行 \\ 仁真会白鷖病院外科
}

key words : ブラッドアクセス, 人工血管内シャント, 長期成績

〈要旨〉

血液透析のためのブラッドアクセスとして人工血管内シャントは，長期成績が不良であることが問題とされてき た. しかし, 近年ブラッドアクセストラブルの治療法としてインターベンション治療が導入され, シャントが閉塞 する前にアクセス不全を発見するための surveillance も導入されるようになり, 人工血管内シャントの開存成績が 向上するものと期待される. そこで, 1996 年 1 月から 2000 年 12 月の 5 年間にブラッドアクセスとして使用した人 工血管 362 本の長期成績を，2001 年 12 月までの 6 年間を観察期間とし検討した。使用した人工血管は expanded polytetrafluoroethylene 製 342 本，polyurethane 製 20 本で，植え込み部位は前腕 170 本，前腕一上腕 78 本，上腕 108 本，乥の他 6 本であった。経過観察期間中の主要な合併症は血栓閉塞 $38.7 \%$, 静脈狭窄 $37.8 \%$, 感染 $7.2 \%$

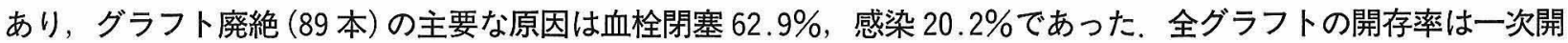
存が術後 1 年, 2 年, 3 年, 4 年においてそれぞれ $48.4 \%, 32.2 \%, 20.5 \%, 13.4 \%$,であり, 二次開存が術後 1 年, 2 年，3 年， 4 年， 5 年においてそれぞれ，81.9\%，77.1\%，69.0\%，54.7\%，50.8\%であった。年次別二次開存率 は, シャント狭窄に対する surveillance とインターベンション治療の導入後向上しつつあり, 今後さらに向上するこ とが期待される.

\section{Long-term follow-up of vascular access grafts}

Toshiyuki Hiranaka

Division of Surgery, Shirasagi Hospital

Secondary patencies for vascular access grafts remain less than expected. However, the recent introduction of interventional radiological treatments and surveillance for vascular access failure may improve the secondary patency of vascular access grafts. We reviewed our six-year experience with 362 arterio-venous graft implantation procedures for hemodialysis. Graft materials were expanded polytetrafluoroethylene in 342 cases, and polyurethane in 20 cases. Graft locations were the forearm in 170 cases, forearm-upper arm in 78 cases, upper arm in 108 cases, and other sites in 6 cases. Major complications during the follow-up period were thrombosis $(38.7 \%)$, venous stenosis $(37.8 \%)$, and infection $(7.2 \%)$. Graft loss occurred in 89 cases and the major causes of graft loss were thrombosis (62.9\%) and infection (20.2\%). Primary patency rates of all grafts at 1, 2, 3, and 4 years were $48.4 \%, 32.2 \%, 20.5 \%$, and $13.4 \%$, respectively. Secondary patency rates of all grafts at 1 , $2,3,4$, and 5 years were $81.9 \%, 77.1 \%, 69.0 \%, 54.7 \%$, and $50.8 \%$, respectively. Introduction of interventional radiology for vascular access failure and surveillance for vascular access stenosis may further promote the secondary patency of vascular access grafts.

\section{はじめに}

血液透析のためのブラッドアクセスとして，自己動 静脈内シャントが第一選択であることは異論のないと
ころである。しかし，透析患者の高齢化や糖尿病性腎 症の増加に伴い, 自己動静脈を用いた内シャントが作 製困難であるため人工血管を使用せざるを得ない症例 が増加している. 人工血管内シャントの問題点として, 血栓閉塞の頻度が高く, 開存率も低いらことが指摘さ

平中 俊行 仁真会白䉆病院外科 T 546-0002 大阪市東住吉区杭全 7-11-23

Toshiyuki Hiranaka Tel : 06-6714-1661 Fax :06-6719-6169

〔受付：平成 15 年 1 月 16 日, 受理 : 平成 15 年 3 月 14 日〕 
表 1 Patient characteristics

\begin{tabular}{ll}
\hline Number of patients & 362 \\
Sex (male/female) & $134 / 228$ \\
Age (years) & $62.2 \pm 11.8$ \\
& \multicolumn{1}{c}{$\quad$ (range $: 14 \sim 88)$} \\
Diabetes (\%) & $132(36.5)$ \\
Previous access procedures & 2.6 (range $: 0 \sim 24)$ \\
Mean duration of dialysis & $1,709$ (range $: 0 \sim 9,888)$ \\
\hline
\end{tabular}

れている。しかし, 近年ブラッドアクセストラブルに 対するインターベンション治療が導入され ${ }^{2)}$, シャン トが閉塞する前にアクセス不全を発見する目的で surveillance ${ }^{3)}$ も実施されるようになり，今後人工血管内 シャントの開存成績は向上するものと期待される。 こで，これまで行った人工血管内シャント作製術の長 期成績の検討を行った.

\section{I. 対象と方法}

1996 年 1 月から 2000 年 12 月の 5 年間に, 自己動静 脈内シャントが作製困難のためブラッドアクセスとし て人工血管内シャントを作製した 362 症例を対象と し，観察期間は 2001 年 12 月までの 6 年間とした。性 別は男 134 例, 女 228 例, 手術時平均年齢 62.2 歳, 糖 疗病を合併する症例は 132 例（36.5\%）であった（表 1).使用した人工血管は expanded polytetrafluoroethylene (ePTFE) 製 342 本 $(6 \mathrm{~mm}$ straight 272 本, 4-6 mm tapered 69 本, $5 \mathrm{~mm}$ straight 1 本), polyurethane (PU) 製 20 本 (5 mm 13 本, $6 \mathrm{~mm} 7$ 本) であった（表 2)，植え込み部位と型式は前腕ループ型 170 例, 前腕一肘上部ループ型 78 例, 上腕ループ型 108 例，その他 6 例（前腕ストレート型 1 例，上腕カーブ 型 1 例, 上腕-前胸壁カーブ型 1 例, 大腿ループ型 3 例) であった（表 3). 1996 年 1 月から 1997 年 2 月までの 間はす心゙て上腕に植え込み，それ以降は前腕ループ型 を第一選択とし，肘窩部で適当な静脈をみつけられな い場合は，静脈吻合を肘上部で行う方針とした。手術 は上腕一前胸壁症例を除き，すべて局所麻酔下に行い, 人工血管と動・静脈との吻合は, cv-6 Gore-Tex ${ }^{\circledR}$ suture を用いて端-側に連続縫合で行った，術後の抗 生剤は cefotiam hydrochloride $1 \mathrm{~g} /$ 日を 3 日間使用 し, シャント閉塞を予防する目的での抗凝固療法や抗 血小板療法は原則的に行わなかった。

グラフト閉塞に対しては，外科的血栓除去術と静脈 延長術あるいは経皮的血管形成術（PTA）を行った が, 2000 年 11 月からはインターベンション治療らを優 先して行う方針とした。.また，1998 年 4 月から術後 3
表 2 Graft types

\begin{tabular}{|c|c|c|}
\hline $6 \mathrm{~mm}$ & PTFE & $272(75.1)$ \\
\hline $4 \sim 6 \mathrm{~mm}$ & PTFE & $69(19.1)$ \\
\hline $5 \mathrm{~mm}$ & PTFE & $1(0.3)$ \\
\hline $6 \mathrm{~mm}$ & Polyurethane & $7(1.9)$ \\
\hline $5 \mathrm{~mm}$ & Polyurethane & $13(3.6)$ \\
\hline Total & & $362(100.0)$ \\
\hline
\end{tabular}

表 3 Graft locations and configurations

\begin{tabular}{l|rrrrr|r}
\hline & '96 & '97 & ' 98 & '99 & '00 & Total \\
\hline 前腕ストレート型 & - & - & - & - & 1 & 1 \\
前腕ループ型 & - & 16 & 52 & 54 & 48 & 170 \\
前腕-肘上部ループ型 & - & 15 & 28 & 12 & 23 & 78 \\
上腕カーブ型 & - & - & - & 1 & - & 1 \\
上腕ループ型 & 33 & 26 & 20 & 11 & 18 & 108 \\
上腕-前胸壁カーブ型 & 1 & - & - & - & - & 1 \\
大腿ループ型 & - & - & - & - & 3 & 3 \\
\hline \multicolumn{1}{c}{ Total } & 34 & 57 & 100 & 78 & 93 & 362 \\
\hline
\end{tabular}

か月時のシャント造影検査を導入し, 狭窄病変に対し ては予防的 PTAを行った. 2000 年 1 月からシャント 狭窄の surveillance 法として, 希釈法によるアクセス 血流量測定を ${ }^{6 \sim 8)}, 2001$ 年 2 月から超音波パルスドッ プラ法によるアクセス血流量測定 ${ }^{9,10)}$ を導入し, DOQI ガイドライン ${ }^{3)}$ 準じて, 血流量低下時には PTA また は外科的再建術を行う方針とした。

グラフトの開存率は Kaplan-Meier 法で算出し, 開 存率の比較は log-rank test を用い, $\mathrm{p}<0.05$ を統計学 的有意差とした。何ら救済処置を行わない状態でのグ ラフトの開存を一次開存とし，救済処置を含めたグラ フトの開存を二次開存とした.

\section{II. 結 果}

\section{1. 合併症 (表 4)}

経過観察期間中の主要な合併症は, 血栓閉塞 140 本 (38.7\%), 静脈狭窄 137 本 $(37.8 \%)$, 感染 26 本 $(7.2 \%)$ であった。術後 30 日以内の早期閉塞は 11 本 (3.0\%) であり，このうち 2 本はグラフト感染に伴うもので あった，グラフト感染 26 本のうち, 術後 30 日以内の 早期感染は 3 本 $(0.8 \%)$ であり，それ以降の晩期感染 は 23 本 $(6.4 \%)$ であった。

\section{2. グラフト廃絶（表 5)}

グラフト廃絶は 89 本であり, 主要な原因は血栓閉塞 56 本 $(62.9 \%)$, 感染 18 本（20.2\%）であった。

\section{3 . 生命予後}

死亡症例は 70 例あり, メチシリン耐性黄色ブドウ球 
表 4 Complications during the study

\begin{tabular}{lc}
\hline & Grafts (\%) \\
\hline Thrombosis & $140(38.7)$ \\
Stenosis & $177(48.9)$ \\
Venous & 137 \\
Graft & 34 \\
Arterial & 6 \\
Infection & $26(7.2)$ \\
Skin erosion & $15(4.1)$ \\
Central vein stenosis & $12(3.3)$ \\
Heart failure & $12(3.3)$ \\
Seroma & $11(3.0)$ \\
Steal syndrome & $3(0.8)$ \\
Pseudoaneurysm & $2(0.6)$ \\
\hline
\end{tabular}

表 5 Graft loss $(n=89)$

\begin{tabular}{lr}
\hline \multicolumn{1}{c}{ Cause } & Number $(\%)$ \\
\hline Thrombosis & $56(62.9)$ \\
Infection & $18(20.2)$ \\
Central vein stenosis & $5(5.6)$ \\
Heart failure & $4(4.5)$ \\
Seroma & $2(2.2)$ \\
Steal syndrome & $2(2.2)$ \\
Others & $2(2.2)$ \\
\hline \multicolumn{1}{c}{ Total } & $89(100)$ \\
\hline
\end{tabular}

菌によるグラフト感染から敗血症となった 1 例を除 き，死因は人工血管植元込み手術と関連したものでは なかった。グラフト植え込み期間中の生存率は，1年 $87.2 \%, 3$ 年 $76.2 \%, 5$ 年 $65.5 \%$ であり, 1996 年透析 導入患者の生命予後 ${ }^{11)}$ とほ漂同等であった（図 1 ).

\section{4. 年次別術後 1 年目開存率}

術後 1 年目に扮ける年次別開存率は，表 6 に示すと 扔りである. 1996 年はすべて上腕に植光込んでおり， 一次開存率，二次開存率とも良好であった。1997 年 2 月以降は前腕に植え込むことを優先した結果, 一次開 存率, 二次開存率とも低下した。 その後, 一次開存率 は低下しているが，二次開存率は上昇傾向にある。

\section{5. 植え込み部位と開存率}

植え込み部位別の開存率は図 2,3 亿示すと扔りであ る。一次開存率は前腕症例より上腕症例が有意に良好 であったが $(\mathrm{p}=0.04)$, 二次開存率は前腕症例が有意 に良好であった $(p=0.006)$ 。また，動・静脈吻合とも 肘窩部で行った前腕症例と動脈吻合を肘窩部で，静脈 吻合を肘上部で行った前腕一上腕症例とを比較すると， 一次開存率，二次開存率とも有意差を認めなかった $(\mathrm{p}=0.27, \mathrm{p}=0.63)$.

\section{6. グラフト素材と開存率}

$\mathrm{PU}$ グラフトの術後 1 年に抢ける一次開存率は

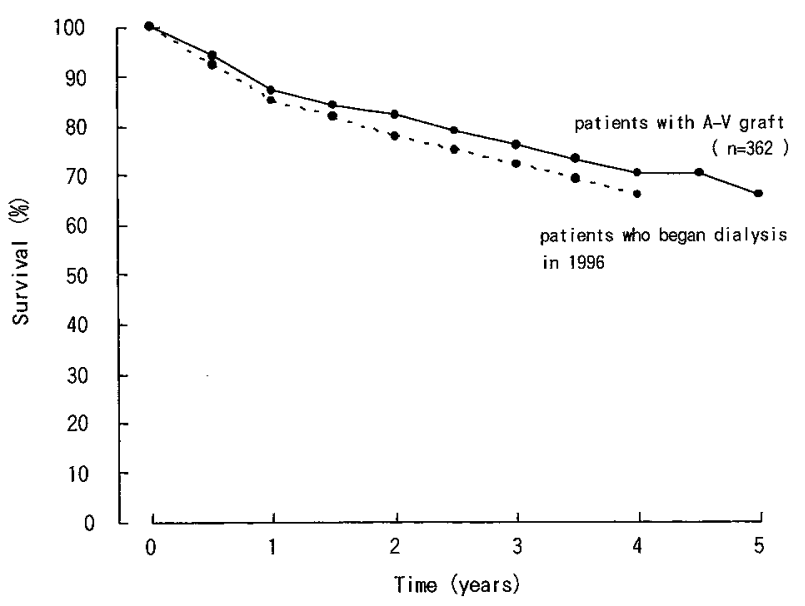

図 1 Patient survival with $\mathrm{A}-\mathrm{V}$ graft

表 6 Praimary and secondary patency at 1 year

\begin{tabular}{cccccc}
\hline & ' 96 & ' 97 & '98 & '99 & '00 \\
\hline 一次開存率 (\%) & 76.7 & 58.8 & 53.2 & 37.4 & 36.9 \\
二次開存率 (\%) & 83.7 & 79.7 & 81.2 & 81.1 & 84.0 \\
\hline
\end{tabular}

$25.0 \%$, 二次開存率は $74.0 \%$ あった(図 4). しかし， PU グラフドは使用数が 20 本 (5.5\%) と少なく, 観察 期間も短いため, ePTFE グラフトと比較することは できなかった。

7. 全グラフトの開存率（図 5,6)

一次開存率は術後 1 年, 2 年, 3 年, 4 年比扔いてそ れぞれ 48.4\%，32.2\%，20.5\%，13.4\%であり，二次 開存率は術後 1 年, 2 年, 3 年, 4 年, 5 年においてそ

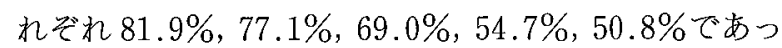
た。

\section{III. 考 察}

わが国における人工血管内シャントの長期成績は, 二次開存率が術後 5 年で $30 \sim 40 \%$ と報告されてい $3^{1,12,13)}$. グラフト廃絶の主要な原因は血栓閉塞であ り, 血栓閉塞した人工血管内シャントの $85 \%$ 以上はな んらかの狭窄病変を伴っている ${ }^{14,15)}$. 従って, 人工血管 内シャントにおける最大の問題点は, 流出路静脈にお ける内膜過形成 (neointimal hyperplasia; NH) の発 生 ${ }^{16)}$ ということになる. しかし, NH の発生機序はいま だ明らかにされて扔らず，有効な予防法も確立されて いないため, 現時点においてはシャントが閉塞する前 に狭窄を発見し，これに対して適切な処置を行うこと が NH に対する対処法であり, 人工血管内シャントの 寿命を延長する方法と考えられる。

今回のわれわれの検討においても，人工血管内シャ 


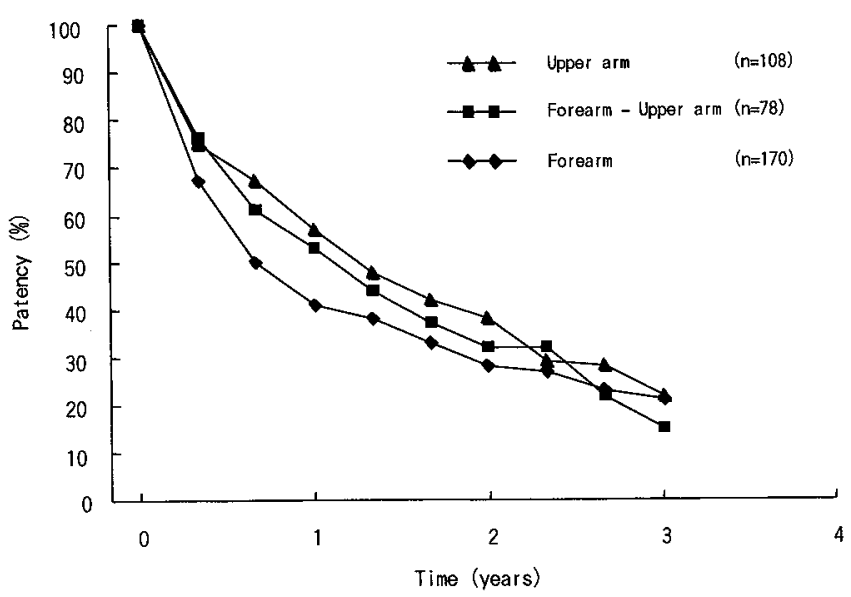

図 2 Primary patency - graft location-

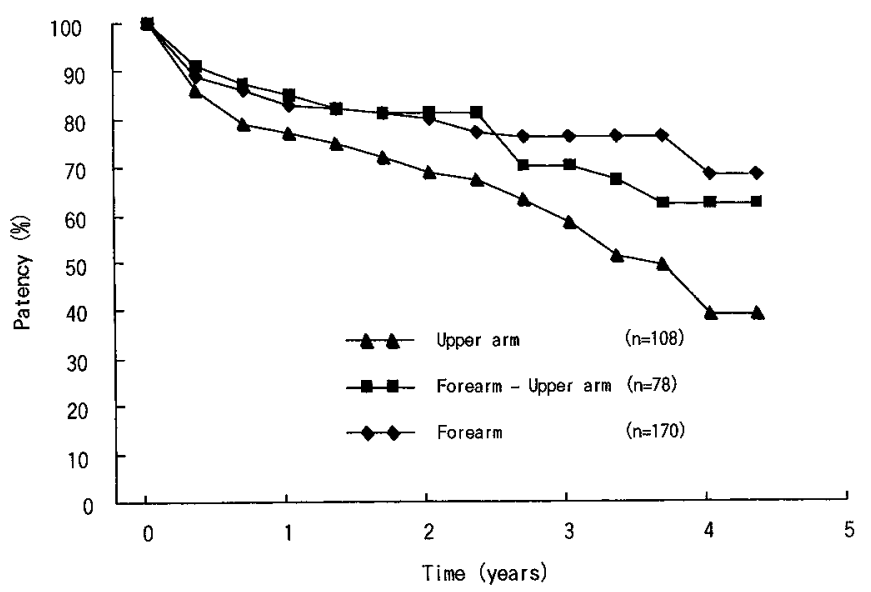

図 3 Secondary patency - graft location-

ントの合併症として頻度が高かったのは血栓閉塞，静 脈狭窄，感染の順であり，グラフト廃絶の主要な原因 は血栓閉塞と感染であった。シャント狭窄に対する surveillance として, 静脈圧, 再循環率, 透析量, アク セス血流量の測定があげられ，なかでもアクセス血流 量測定が有用であると報告されている゙．われわれの 施設では 2000 年 1 月からクリットラインモニター® を用いて希釈法によるアクセス血流量測定を開始し， 血流量が $600 \mathrm{~mL} / \mathrm{min}$ 以下となれば造影検査を施行 し, 狭窄病変が発見されればPTA または外科的再建 術を行う方針としている8).これにより 2000 年度の術 後 1 年目の二次開存率は向上したものと考えている. また，最近では超音波ドップラー法を用いたアクセス

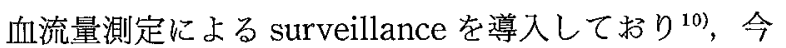
後さらに開存率の向上が期待される。

グラフト感染の頻度に関しては, 酒井ら ${ }^{177}$ は $10.5 \%$ ，出川ら ${ }^{12)}$ は $12.2 \%$ と報告している。 今回のわ れわれの検討では, 植え込み術後 30 日以内の早期感染

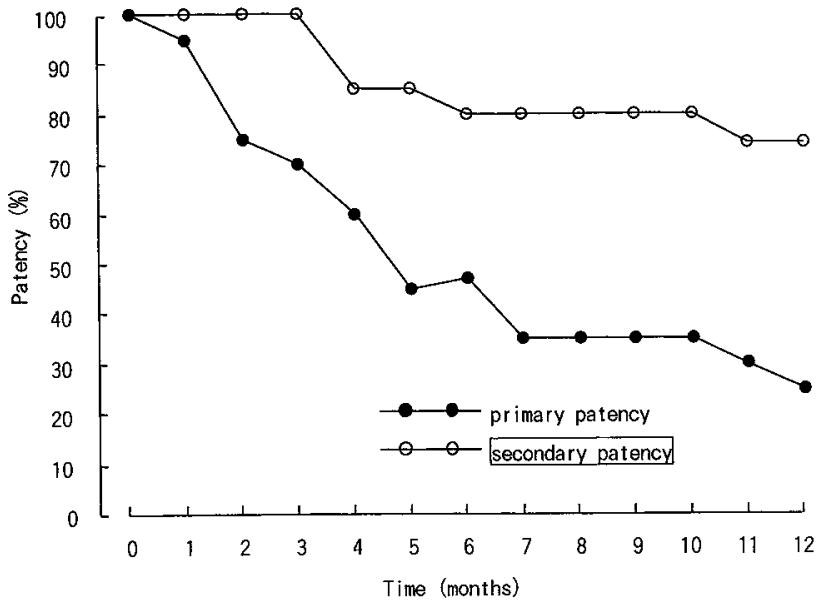

図 4 Primary and secondary patency of PU grafts

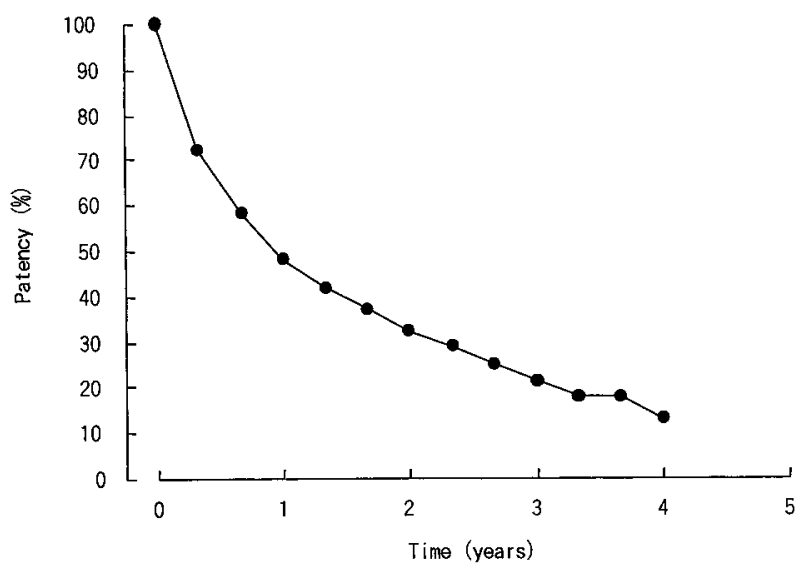

図 5 Primary patency of $362 \mathrm{~A}-\mathrm{V}$ grafts

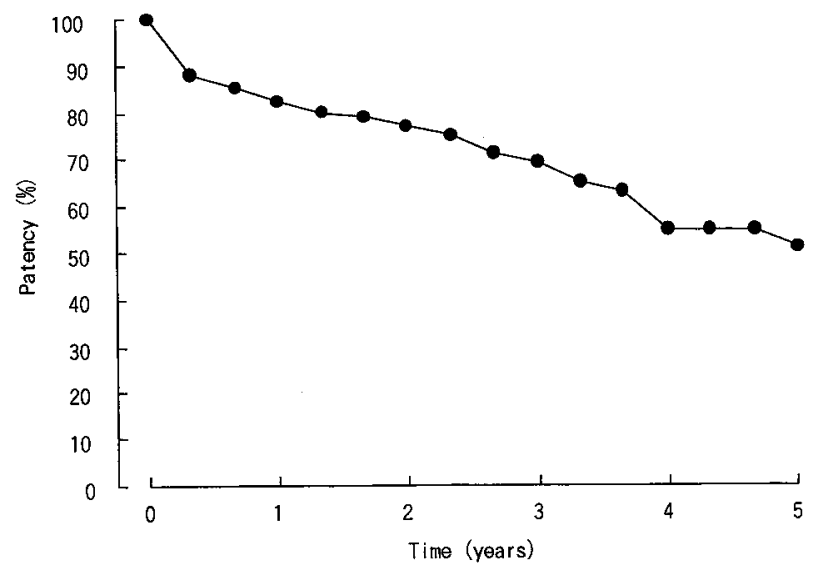

図 6 Secondary patency of 362 A-V grafts

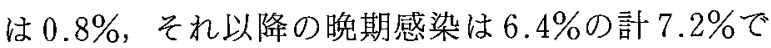
あった。しかし，われわれの施設で維持透析を受けて いる患者に限れば, 1996 年から 2001 年の 6 年間で 115 本中 3 本 $(2.6 \%)$ であり, 発生頻度は 0.01 回/患者· 年と低率であった ${ }^{18)}$. 穿刺・止血操作時の感染防止を 徹底することにより, 感染の頻度は低下させることが 
可能と考えられる.

人工血管の材質に関しては，従来から使用されてい る $\mathrm{ePTFE}$ と最近使用されるようになった PUがある が，われわれは PU の使用本数が少なく，使用期間も ePTFE グラフトより短いために, 開存率を比較する ことはできなかった，PUグラフトの早期成績は

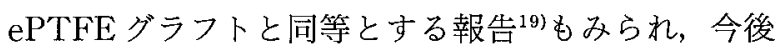
の検討課題であると考えている.また, ePTFE グラフ トにはさまざまな種類があり，形態においてもテー パー型やカフ付きグラフトが存在するが, これらが開 存率の向上に寄与したとの明白な根拠は存在しな $\iota^{20,21)}$.

人工血管の植え込み部位と開存率に関しては, 前腕 より上腕や大腿が良好 ${ }^{22)}$ との意見と, 植え込み部位に

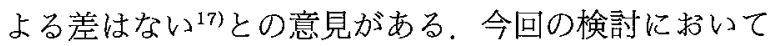
も，1996 年度に植え込んだ上腕症例は, 術後 1 年目の 一次開存率，二次開存率とも良好であった。しかしな がら，その後前腕に植え込むことを優先する方針とし， 積極的に PTA や外科的修復術を施行した結果, 全体 としての二次開存率は上腕症例より前腕症例のほうが 良好となった．アクセスの管理法が経年的に変化して いること，前腕に植え込んだ症例も延長術を行う場合 には上腕の静脈を使用していることを考慮すれば，前 腕と上腕とを公正に比較できているとはいえない，長 期間ブラッドアクセスを維持する必要があることを考 えれば，まず前腕に植え込み，救済が不可能となれば 新たに上腕に植え込む方針で良いと考えられる。

\section{結 語}

人工血管内シャントの長期成績は, 術後 5 年で $50.8 \%$ に到達した。これにはインターベンション治療 やアクセス不全に対する surveillance の導入が寄与 したものと考えられ，今後さらに向上することが期待 される。

\section{文献}

1）大平整爾, 阿部憲司, 今 忠正：ブラッドアクセスの 長期開存性および関連する危険因子. 臨牀透析 12 ： $155-165,1996$

2) Beathard GA : Percutaneous angioplasty for the treatment of venous stenosis: A nephrologist's view. Semin Dial 8:166-170, 1995

3) National Kidney Foundation:DOQI clinical practice guidelines for vascular access. Am J Kidney Dis 30 (Suppl 3) : S 150-S 191, 1997

4）平中俊行, 山川智之, 金 昌雄：グラフト内シャント
閉塞に対する外科的治療成績の検討. 阪透析会誌 18 ： 43-45，2000

5) Voweek D, Schon M, Schurman K, Hoogeveen $Y$, Gladziwa U, Guenther RW : Hydrodynamic thrombectomy of hemodialysis fistulas: First clinical results. J Vasc Interv Radiol 5 : 813-821, 1994

6) Krivitsky NM: Theory and validation of access flow measurement by dilution technique during hemodialysis. Kidney Int 48:244-250, 1995

7) Lindsay RM, Bradfield C, Rothera C, Kianfar P, Malek P, Blake PG : A comparison of methods for the measurement of hemodialysis access recirculation and access blood flow rate. ASAIO J $44: 62-67$, 1998

8）平中俊行：内シャントのモニタリング. 阪透析会誌 19:59-61, 2001

9) Bay WH, Henry ML, Lazarus JM, Lew NL, Ling J, Lowrie EG : Predicting hemodialysis access failure with color flow doppler ultrasound. Am J Nephrol 18:296-304, 1998

10）吉本勝美, 武田理子, 坂井久美, 元上七奈, 南 伸治, 小北克也, 内田麻希, 大年辰幸, 出雲谷剛, 平中俊行： パルスドップラー法による人工血管内シャントの血流 量測定一稀釈法との比較一. 阪透析会誌 $19: 31-95$, 2001

11）日本透析医学会統計調查委員会：わが国の慢性透析療 法の現況（2001 年 12 月 31 日現在）, p 163, 日本透析 医学会, 東京, 2002

12）出川寿一, 多川 斉, 冨川伸二, 内田久則 : E-PTFE グラフトを用いたブラッドアクセスの長期成績。透析 会誌 $28 ： 1359-1365,1995$

13）酒井信治：人工血管使用のブラッドアクセス，臨牀透 析 $12: 896-906,1996$

14) Palder SB, Kirkman RL, Whittemore AD, Hakim RM, Lazarus JM, Tilney NL : Vascular access for hemodialysis : Patency rates and results of revision. Ann Surg 202 : 235-239, 1985

15) Rajyu S : PTFE grafts for hemodialysis access: Techniques for insertion and management of complications. Ann Surg 206 : 666-673, 1987

16) Hurt AV, Battello-Cruz M, Skipper BJ, Teaf SR, Sterling Jr WA : Bovine carotid artery heterografts versus polytetrafluoroethylene grafts. A prospective, randomized study. Am J Surg $146: 844-847$, 1983

17）酒井信治，平沢由平：過去 5 年間に経験したゴアテッ クス ${ }^{\circledR} \mathrm{E}-\mathrm{PTFE} ク ゙ ラ フ ト 161$ 例の成績とその評価. 腎と透析 $13: 41-47,1982$

18）比良宏美, 上田宏子, 坂元さおり, 谷口聖子, 一八瀬 正子, 真砂智美, 田中里美, 平中俊行：当院に抢ける グラフト内シャント管理と感染率について. 阪透析会 誌 $20: 264,2002$

19）大坪 茂, 森 典子, 長井幸二郎, 松尾 研, 前原陽 
子, 新田孝作, 秋葉 隆, 二瓶 宏: 血液透析患者任 扔けるポリウレタン製人工血管 (Thoratec ${ }^{\circledR}$ Vascular Access Graft, TVAG) と Expanded Polytetrafruoroethylene Graft (EPTFG) の早期開存率の比較. 透析会誌 35：1125-1129，2002

20) Hiranaka $T:$ Tapered and straight grafts for hemodialysis access: A prospective, randomized comparison study. In "Vascular access for hemodialysis-VII" ed Henry ML, p 219-225, W. L.
Gore \& Associates, and Precept Press, Chicago, 2001

21）平中俊行，木村英二，中村順一，山川智之，金 昌雄, 奥野仙二, 加藤禎一：新しい透析用人工血管 Venaflo ${ }^{\circledR}$ の使用成績．透析会誌 $34 ： 1313-1317 ， 2001$

22）高須伸治, 高津成子, 岡 良成, 国米欣明：人工血管 （E-PTFE グラフト）による内シャント術一作製部位 別検討を中心に一. 透析会誌 $27: 939-941,1994$ 